\title{
Forest sector in a green economy: a paradigm shift in global trends and national planning in Sri Lanka
}

\author{
Nimal Gunatilleke \\ Department of Botany, Faculty of Science, University of Peradeniya, Peradeniya.
}

Submitted: 27 November 2014; Accepted: 22 April 2015

\begin{abstract}
The concept of 'green economy' has been brought into the mainstream policy discourse at the international level as a powerful tool in achieving sustainable economic development that promotes human well-being. Forests produce a range of both tangible and intangible ecosystem services and have an enormous potential to contribute to green economy. Despite being fundamental to the well-being of humanity, the natural capital that includes forests remain grossly undervalued or not valued at all within our conventional economic systems. Economic valuation of ecosystem services will enable better decision making, innovative and challenging investment opportunities, novel horizons for wealth creation and jobs in a green growth sector. At global scale, there is a paradigm shift to include the values of natural capital into national accounting and reporting system. Greening of the economy of Sri Lanka has the potential to be the new engine of growth, a new generation of green employment opportunities in a range of important sectors including forests. Capturing the true contribution of the forest sector to green economy would help to internalize the wholesome value of forest ecosystem services, which would ensure that the forests are worth much more when standing than when cleared for alternative land uses. The National Physical Plan for Sri Lanka (2011-2030) has correctly identified a 'Central Fragile Area' for environmentally friendly development. Over 133,600 ha of environmentally sensitive areas within this critical watershed that are presently under poorly managed cash crop cultivation have been identified for reforestation. This being the main catchment area of the entire country, the choice of species for reforestation needs critical scientific assessment as there are emerging environmental concerns over establishment of large scale monoculture plantations of fast growing tree species to meet the commercial scale timber and fuel wood requirements in such critical watersheds. Therefore, a new vision and a strategy is imperative in the light of the emerging scenarios of ecosystem services of forest sector in a green economy in Sri Lanka. Highest priority in forestry research and development should therefore be given for restoration of vital ecosystem services in mountain watersheds of the central fragile area.
\end{abstract}

Keywords: Central fragile area, ecosystem services, forests, green economy, national physical plan.

\section{INTRODUCTION}

The United Nations Environment Programme defines a green economy as one that is low-carbon, resource efficient and socially inclusive, which would result in improved human well-being and social equity, while significantly reducing environmental risks and ecological scarcities (UNEP, 2011). In a green economy, growth and employment are driven by public and private investments that reduce carbon emissions and pollution, enhance energy and resource efficiency, and minimize the loss of biodiversity and ecosystem services. The strategic objective in the transition to a green economy is therefore, to facilitate economic growth and investment while at the same time taking measures to enhance environmental quality and social inclusiveness leading to sustainable development. According to an IMF report in 2006, the world economy has quadrupled over the last quarter century, but concurrently on the flip side, 60 percent of the world's major ecosystem goods and services that underpin livelihoods have been degraded or used unsustainably (MA, 2005).

\section{Role of forest sector in the global economy}

Global forests as a whole are estimated to contribute around US $\$ 468$ billion or approximately one percent to the world's GDP. The share of the formally recognized and officially reported monetary contributions of forests to the economies of the developing world seem to exceed US\$ 250 billion, which is more than the annual global output of gold and silver combined, and double 
the development assistance received by these countries (Agrawal et al., 2013). Nonetheless, this figure includes only the cash exchange-based contributions derived primarily from the round wood production, processing of timber and timber products including pulp and paper manufacture. This does not however, include the broad range of both tangible and intangible 'ecosystem services' that forests provide. These ecosystem services provided by forests in particular, are critically important for our well-being, which in common parlance is known as 'health, wealth and happiness'. They include the most obvious ones such as the food we eat, the fresh water we drink and the clean air we breathe, essentially the primary life support systems. Then we obtain plant materials such as fire wood, medicinals (Weni welgeta, Kothala himbutu etc.) and aromatics (Walla of recent fame) and other forest raw materials for our industries and consumption. Though less obvious, forests and other such green spaces sustain the processes that purify air and water, breakdown waste products, sequester carbon, cycle nutrients and maintain soil fertility, all of which we take for granted and hardly pay any attention to.

\section{Forests and ecosystem services}

Forests also perform regulatory functions such as flood control, climate amelioration, air and water quality regulation, pest and disease control and supporting services such as pollination, seed dispersal, nutrient cycling and primary production of foods mostly by fixing carbon dioxide that is available in the atmosphere. Likewise, they also provide invaluable cultural services such as spiritual, aesthetic, recreational and educational values for the wholesome well-being of humans and all other living organisms. Yet today, all these life support systems collectively known as ecosystem services provided by the forests and other such landscapes are largely taken for granted and perceived as 'public benefits or free lunches' in modern society's balance sheet. Despite being fundamental to the well-being of human societies, critical contribution of ecosystem services have hitherto been overlooked in public, corporate and individual decision making processes. In contrast, these non-market values of ecosystem services were better appreciated and virtually revered by our forefathers in their own unique cultural value systems. Such value systems for the ecosystem services rendered by forests and wetlands in particular, are still preserved in our world-renowned 'cascade system of irrigation' in Sri Lanka. Increasingly disturbing trends of biodiversity loss and the impacts of climate change are leading to growing realization the world over that 'there is no free lunch forever' with respect to the natural capital, which includes air, water, soil, geological resources (i.e. minerals including precious stones) and all living organisms.

\section{Focus: Consequences of Ecosystem Change for Human Well-being}

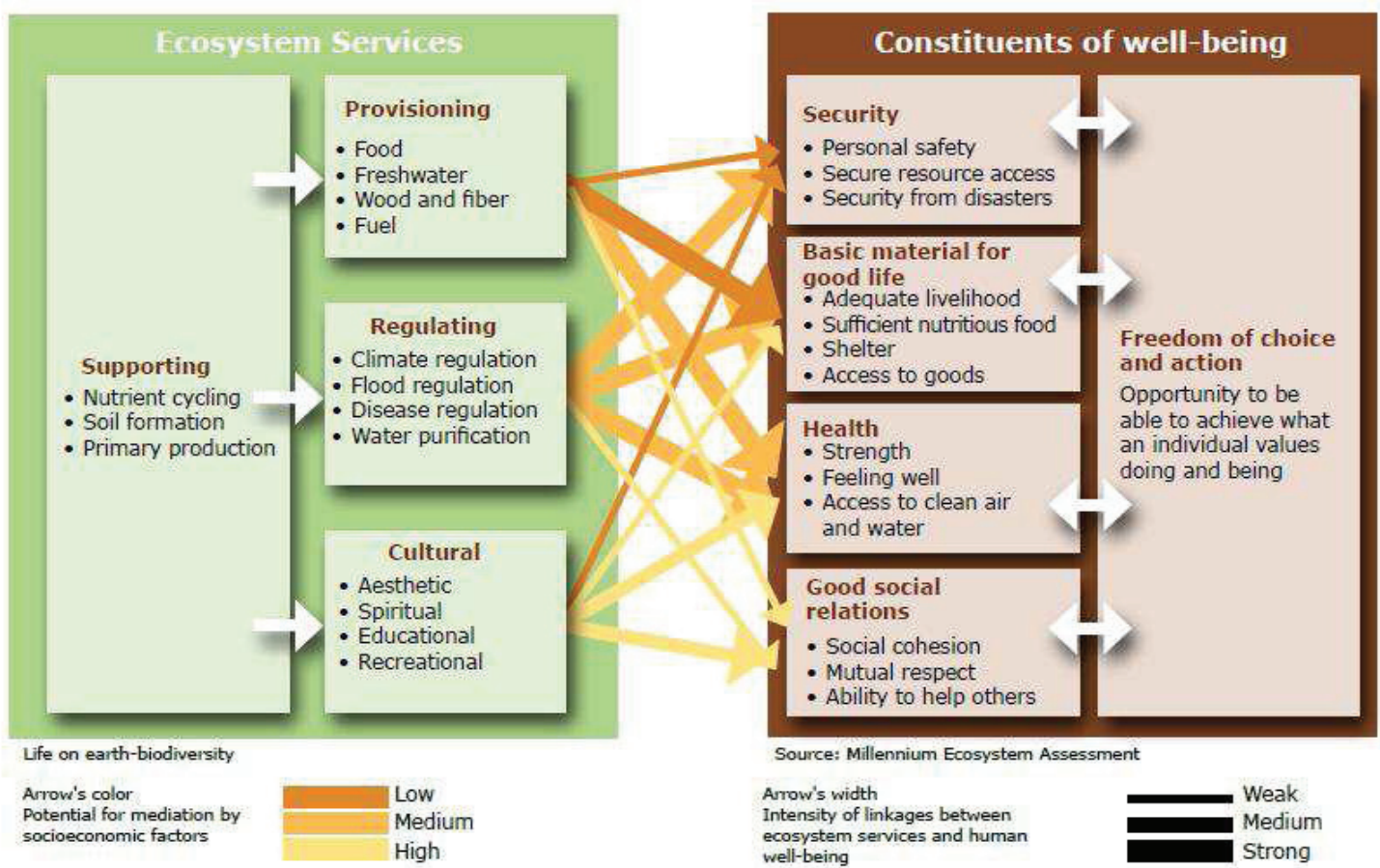

Figure 1: $\quad$ Ecosystem services and their linkages with human well-being (MA, 2005). 
The Millennium Ecosystem Assessment (MA) report presented to the United Nations in 2005 assessed the consequences of ecosystem change on human well-being. This report also examined the scientific basis for action needed to enhance the conservation and sustainable use of those ecosystems and their contribution to human wellbeing (Figure 1). One of the major findings of the MA is that human actions are depleting Earth's natural capital, putting such strain on the environment that the ability of the planet's ecosystems to sustain future generations can no longer be taken for granted.

The global natural capital has its own limits, which are designated as 'planetary boundaries'. Several components of this capital have been driven almost beyond the threshold tipping point and are on the verge of reaching a point of no return (i.e. global biodiversity, climate change and global nitrogen cycling). Although nature is priceless, the natural capital should not be treated in economic portals as 'valueless' any longer. Moreover, the MA showed that with appropriate actions it is possible to reverse the degradation of many ecosystem services over the next 50 years, but the necessary policy changes and required practices are substantial and unfortunately not yet underway.

\section{Economic valuation of ecosystem services}

The modern-day resource economists have taken up the challenge of calculating the world's natural capital in financial terms. According to the more recent estimates, conserving the global forests would be worth US\$ 3.7 trillion a year considering its role in reducing greenhouse gas emissions alone. Likewise, their role in insect pollination is worth US\$ 190 billion a year to global agricultural output (MA, 2005). Although difficult at present, valuation of other services that forests offer would be much higher than that the Food and Agriculture Organization (FAO) has given for timber and paper pulp. Despite being fundamental to the well-being of our society, the natural capital and services that forests provide remain grossly undervalued or not valued at all within our conventional economic system.

Undervaluing or treating the overall benefits that we derive from the natural capital and its constituent ecosystems as 'valueless' in modern accounting systems, is leading these ecosystems to steady degradation. Most importantly, the conventional economic valuations tend to ignore the 'sustainability potential' of the resource base thus making ill-informed decisions (Gunatilleke, 1988). A good example of this is the so called 'sustainable forest/timber management' of Sri Lanka's moist forests. This programme has never been sustainable in its practical sense as sustainability of ecosystem services were not taken into the equation of long-term economic viability during its design. The timely intervention of the environmentally conscious public of the day forced the then government of Sri Lanka to shelve the so called 'Master Plan for Sustainable Forest/Timber Management of Sri Lankan Forests', and a moratorium for logging in natural forests was introduced in 1989, which is effective even today (Gunatilleke, 1988; Gunatilleke \& Gunatilleke, 1993).

Despite the above enactment, the poorly managed forest ecosystems in Sri Lanka are still under enormous pressure from both legal and illegal land clearing for agriculture, infrastructure development including irrigation and road development projects, and unsustainable forest product extraction, as in the case of ' Walla' in more recent times from the moist forests. Poor management leading to overexploitation of the natural capital can become an ecological liability from the loss of biodiversity, affecting ecosystem productivity and decline in resilience to climate change impacts. As a result, fragile forest areas could become more prone to extreme events such as floods and droughts, which we are already experiencing with increasing frequency and intensity, globally as well as in Sri Lanka. Consequently, the over-indulgence on the 'free lunch' of the natural capital would not only be an ecological liability but also a social and economic liability, leading eventually to calamities moving towards social unrest.

Economic valuation of ecosystem services will enable better decision making, innovative and challenging investment opportunities and novel horizons for wealth creation and jobs as well. Failure to include the valuation of non-market ecosystem services in decision making would result in less efficient and unsustainable resource usage. The long-term benefits received from preserving forests like Sinharaja and Kanneliya-DediyagalaNakiyadeniya complex for conservation of broader ecosystem services would be far greater than that, which can result from sustainable forest/timber management or alternative land use such as planting tea. However, one of the major challenges faced currently is to develop appropriate measuring and monitoring systems to capture the true values of the respective non-market ecosystem services.

Global trends in green economy and green growth opportunities for Sri Lanka

In the final outcome document of the United Nations Conference on Sustainable Development held in June 2012 (Rio + 20 - The Future We Want), the Heads of 
State and Governments, including Sri Lanka, reaffirmed their 'determination to address the theme of the United Nations Conference on Sustainable Development; the theme being a green economy in the context of sustainable development and poverty eradication, and the institutional framework for sustainable development'. They also recognized 'green economy as one of the important tools available for achieving sustainable development' (Rio + 20, 2012).

The Rio+20 agreement calls for taking steps to go beyond Gross Domestic Product (GDP) to assess the wellbeing of a country. In traditional market economics, the macro-economic policies are largely based on information flowing from the System of National Accounts often measured by the GDP. The GDP looks only at one part of economic performance, viz., national income and output, but it does not take into account the sustainability of its wealth or its depletion or growth. For example, when a country exploits its non-renewable natural capital such as forests/mineral resources or fossil fuels, it is actually depleting its wealth, which is not captured in conventional GDP measures. Similarly, pollution and declining of ecosystem services resulting from such activities have thus far been treated as 'environmental externalities' and does not appear as internalized costs anywhere in national accounts.

A recent World Bank publication 'Inclusive Green Growth Report' (2012), critiqued the neo-classical theory of growth (i.e. growth in output GDP comes from increases in physical capital, labour and productivity), because it fails to recognize that economic production depends directly on the stock of natural resources and the quality of the environment. The analytical framework of this report considers how environmental policies can increase conventionally measured GDP through four channels linked to input, efficiency, stimulus and innovation effects.

Having recognized the limitations and inadequacies of GDP as a measure of well-being and sustainable growth that values environmental and social aspects of progress, the world is aiming to move beyond traditional GDP in a green economy and to mainstream their natural capital into their national accounts, to make better informed decisions through the following actions:

i. Develop institutional arrangements to strengthen the implementation of natural capital accounting;

ii. Develop science-based methodologies on an experimental basis for ecosystem accounting as a complement to GDP and corporate performance and to be scaled up later; iii. Pilot and demonstrate the economic, social and environmental aspects of scaled up and integrated approaches to natural capital accounting.

The common perception that the greening of economies inhibits wealth creation and employment opportunities, and that it is a luxury that only wealthy countries could afford, is changing rapidly. Sri Lanka, as many other developing countries in the world, is facing major challenges such as energy insecurity, ecological scarcities and impacts of climate change. A green economy would invest in natural capital for improving human well-being and ensuring social equity while safeguarding environmental and economic integrity. It could open up development paths that are increasingly carbon neutral, promote resource and energy efficiency and lessen environmental degradation. Many green sectors could provide significant opportunities for innovative research on sustainable development, incorporating traditional wisdom and indigenous knowledge with modern science in meeting the above challenges. This is specially significant for a small country like Sri Lanka with a proven history of sustainable development over centuries, while conserving our richly endowed natural capital. Green economy has the potential to be a major driver of far-reaching and innovative policy reforms and changes in business-as-usual economic interests. It provides new economic incentives for investments thus creating a new generation of greener employment opportunities thus helping to reduce poverty in a range of important sectors, viz. agriculture, forestry, fisheries, fresh water and energy.

At global scale, there is a significant paradigm shift to include ecosystem goods and environmental services into national accounting systems. At the 2010 Biodiversity Summit held in Nagoya, Japan, 193 countries agreed to a strategic target, to incorporate the values of biodiversity into national accounting and reporting systems by 2020. A major step towards achieving this vision was taken recently with the adoption by the UN Statistical Commission of the System for Environmental-Economic Accounts (SEEA). The SEEA provides an internationally agreed method on par with the current System of National Accounts (SNA), to account for natural resources such as minerals, timber and fisheries (SEEA, 2012). This was followed by the UN led study 'The Economics of Ecosystems and Biodiversity (TEEB, 2010)', which called for national accounts to be upgraded to include the value of changes in natural capital stocks and ecosystem service flows.

Following the TEEB study in April 2013, a report was published for Business Coalition, viz., Natural Capital at Risk: The Top 100 Externalities of Business. This 
report estimates that the world's primary production and processing sectors are responsible for "environmental externality' costs totalling a staggering US\$ 7.3 trillion annually. Furthermore, the global top 100 environmental externalities (= impacts) are costing the economy world-wide around US\$ 4.7 trillion a year in terms of the economic costs of greenhouse gas emissions, loss of natural resources, loss of nature-based services such as carbon storage by forests, climate change and air pollution-related health costs (Trucost PLC, 2013).

A number of countries around the world are currently in the process of either developing or implementing their 'National Green Growth Development Strategies'. South Korea, Denmark, Germany, UAE and Mexico are among the forerunners of green growth agenda mobilizers at present. South Korea for example, has enshrined green growth in its national development strategy and established a Presidential Committee on green growth.

Sri Lanka, should also be mobilizing its resources towards strengthening its own green growth development strategies in a more scientifically assessable manner.

Among the areas in the forestry sector in Sri Lanka that need to be considered foremost are the following:

i. Capturing the true ecosystem service contributions of forests and associated landscape mosaics (wetlands, stream systems, forest gardens etc.) in the national accounting systems.

ii. Implementation of the strategies for reducing emissions from forest degradation and deforestation and include the role of conservation, sustainable management of forests and enhancement of forest carbon stocks (REDD + ).

iii. Establishing economically and ecologically sustainable forest management and reforestation strategies to provide a broader spectrum of ecological services and indicators for monitoring based on green economic criteria such as eco-labelling or eco-certification and branding of products from sustainably managed mixed-crop plantations and agroforestry systems.

iv. Improving the quality and extent of the island's natural forest capital through re-establishment of connectivity among the remaining fragmented forest areas through forest restoration.

v. Establishing buffer zones and transition zones around core protected areas in line with the Man and the Biosphere concept of the UNESCO.

vi. Considering payments for ecosystem services (PES).
In this respect, the initiatives taken by the Ministry of Environment and Renewable Energy to develop an 'Environmental Economic Accounting' (EEA) mechanism for estimating the value of the forest resources as a first step towards estimating the contributions of the forest sector to the national economy is praiseworthy. The PES system is currently gaining wide acceptance (but not without a share of its critics) in both developed and developing countries. In the PES system the forest land owners are paid annually for providing watershed protection, carbon storage, recreation and biodiversity conservation.

The New York City water utility faced with the need to improve water quality, provides incentives to farmers and owners of forest lands in the up-state catchment areas in Catskill/Delaware watershed, to conserve the forest and adopt environmentally friendly management measures. This has apparently proved far less costly than building water-filtration systems, and the Environmental Protection Agency and the Department of Health of the USA has determined that New York City has an adequate longterm watershed protection programme for the Catskill/ Delaware water supply that meets the requirements for unfiltered water supply systems (Pagiola \& Platais, 2007). Similarly in North-east France one of the largest mineral water bottlers, Perrier-Vittel S.A., pays upstream landowners to follow prescribed management practices for conserving the watershed (Perrot-Maitre, 2006). There are similar sustainable examples from developing countries such as Ecuador and Costa Rica where landowners are compensated for providing ecosystem services via reforestation, sustainable management, preservation and restoration (Echavarria, 2002; Pagiola, 2008). Also in Sri Lanka, there are ample opportunities for researchers to critically examine the feasibility of implementing REDD + schemes at the levels of stream/ river basins, at village, district and provincial levels and finally the entire country. This will capture their true contribution to accounting at each level and eventually at the national accounting system. Thereby it would help to internalize the wholesome value of forest ecosystem services for forest landowners (including mixed-species forest garden-owners) and ensure that forests are worth more when standing than when cleared for alternative land use. Putting a green economic value on forests by recognizing the environmental, economic and social values of forest ecosystem services is one way of promoting conservation and more responsible decision making in the national and regional planning processes. In a study carried out in Sri Lanka, flood attenuation provided by the 7000 ha Muthurajawela wetland near Colombo has been valued at over US\$ 5 million/year (Schuyt \& Brander, 2004; ten Brink et al., 2012). 
Forest management for ecosystem services in Sri Lanka

Sri Lanka has excellent historical examples like the Ellangawa (the cascade system of irrigation water management), which gives due consideration to watershed conservation and to an ingenious design of water management. The Dry Zone landscape mosaic of 'reservoir (tank) - temple - homesteads - paddy fields' system is a proven landscape management strategy, which incorporates the triple bottom line of economic, social and ecological sustainability in development. Likewise, over $70 \%$ of tea cultivation in the Wet Zone of Sri Lanka is in the hands of smallholders, where each family owns less than two hectares mostly in the lowlands. These tea plots are interspersed among their mixed-species homesteads forming a landscape mosaic of foresttea gardens. Some smallholders have even diversified their gardens further by incorporating economically important tree crops as shade trees, spice plants etc. A wholesome environmental economic valuation may find that the ecosystem services and goods provided by such a landscape mosaic may be greater than the conventional monoculture tea plantations, exotic timber plantations or expanding vegetable cultivation in environmentally sensitive mountain areas of Sri Lanka. Rapid expansion of tea/vegetable cultivation at the expense of secondary forests and mixed species tree-crop stands, particularly around the catchments of major river systems such as the forest clusters in and around the Peak Wilderness-Horton Plains complex, Knuckles, Sinharaja and the KanneliyaDediyagala-Nakiyadeniya seems to be adversely affecting the sustainability of Sri Lanka's water resources.

The social impacts of reforestation, comprising large-scale monoculture of exotic cash-crop plantations including fast growing timber plantations and vegetable plots in critical watersheds is very controversial in many countries and Sri Lanka is no exception. There is increasing evidence from countries such as South Africa, where over 1.5 million ha of fast-growing and high-yielding monoculture plantations, mostly of exotic tree species like those of Eucalyptus spread-over into watersheds affecting stream flow and catchment water yield (Dye \& Versfeld, 2007). The National Water Act 1998 of South Africa based on long-term hydrological research has taken measures to regulate the streamflow reduction activities and limit the further spread of afforestation in critical catchments where available water resources are fully or over-committed (van Wilgen \& Richardson, 2012).
Forest management and national physical planning for the future in Sri Lanka

In the Sri Lankan context, the National Physical Planning Policy and Plan (NPP) 2011-2030 (the roadmap for national development) proposes reforestation of areas in the central fragile area (Figure 2) having slopes with a gradient over $60 \%$ in the four districts (Nuwara Eliya, Ratnapura, Kandy and Kegalle) totalling 133,630 ha that are presently under cash-crop cultivation (NPP 2008, Figure 3). This being the main catchment area of almost all the major rivers of Sri Lanka, the choice of species for reforestation needs critical scientific evaluation in the light of emerging evidence from other countries as to the negative impacts of raising fastgrowing exotic monoculture tree plantations in prime watersheds. The Food and Agriculture Organization (FAO) underscores the significance of maintaining cloud forests for the production of water, erosion control and biodiversity preservation by stating that conservation of such forests designated as protected areas should be a national priority (FAO, 2008). There is a huge void in research on restoration of degraded montane cloud forests of Sri Lanka with native species and their economic valuation. Therefore, it is of vital importance that restoration research in mountain areas be given the highest priority in forestry research and development. The conservation of ecosystem services such as water purification and soil formation in the central fragile area of the country, is of utmost importance at a time when there are downstream concerns over the quality (agrochemical residues and Chronic Kidney Disease of unknown etiology) and quantity of water flowing down these river systems. The New York City water supply scheme has judiciously managed the land and the vegetation of the Catskill/Delaware watersheds and paid landowners for conserving ecosystem services for the well-being of downstream populations over several decades by provisioning naturally flowing potable water without having to use an artificial water purification system. In a similar manner, if Sri Lanka's national planning process could aim at emulating what the New York City water supply scheme has achieved over the years, discouraging the indiscriminate use of agrochemicals in their farms in headwaters, the economic benefits of such a venture in Sri Lanka though ambitious on its face value, would be enormous.

Biofuel plantations are also promoted as a green energy source in Sri Lanka as in many other countries in the world. However, some biofuel as well as fast growing timber species selected are known to be heavy 


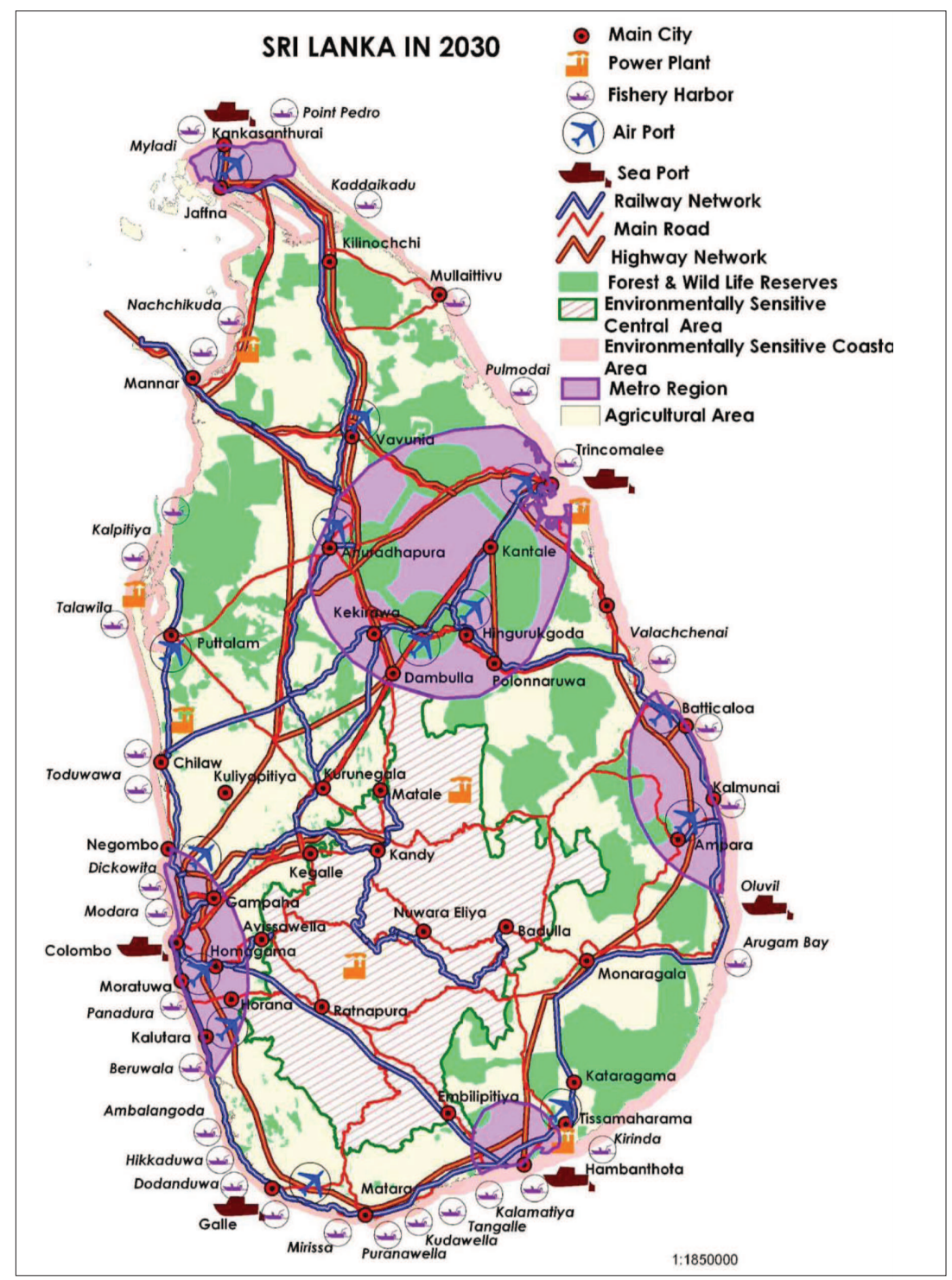

Figure 2: National Physical Structure Plan for Sri Lanka (NPPD, 2010)

water users. Therefore, establishing such plantations in the watersheds without site-specific research would lead to both adverse ecological and economic consequences. These biofuel and fast growing timber species, if selected for large scale reforestation in Sri Lanka's 'Central Fragile Area' will undoubtedly escalate the already existing competition, both for land and for water. Also with other environmentally friendlier land uses such as restored native forests and mixed species forest gardens, specially in some areas of Nuwara Eliya, Badulla, Matale and Kandy Districts where water is already scarce. Therefore in restoration or reforestation initiatives, particularly in hydro-catchments in the central fragile area, 'site-species matching' is a condicio sine qua non.
It is indeed, a challenge Sri Lanka is facing at this crucial phase of rapid development outlined in the National Physical Plan 2011-2030 to engage, at the same time, in an emerging shift towards greening the global economy. However, this opens up a wide range of opportunities for both research and development initiatives in order to realign with the evolving global scenarios in greening the forestry sector as well as in other sectors, so that costly remedial measures could be avoided in the future by visionary planning. Sri Lanka is richly endowed with a religio-cultural heritage that is inextricably linked with its equally rich natural heritage. Sri Lanka has shown that small-holder enterprises could be a major stakeholder in our major export commodities such as tea, rubber and 


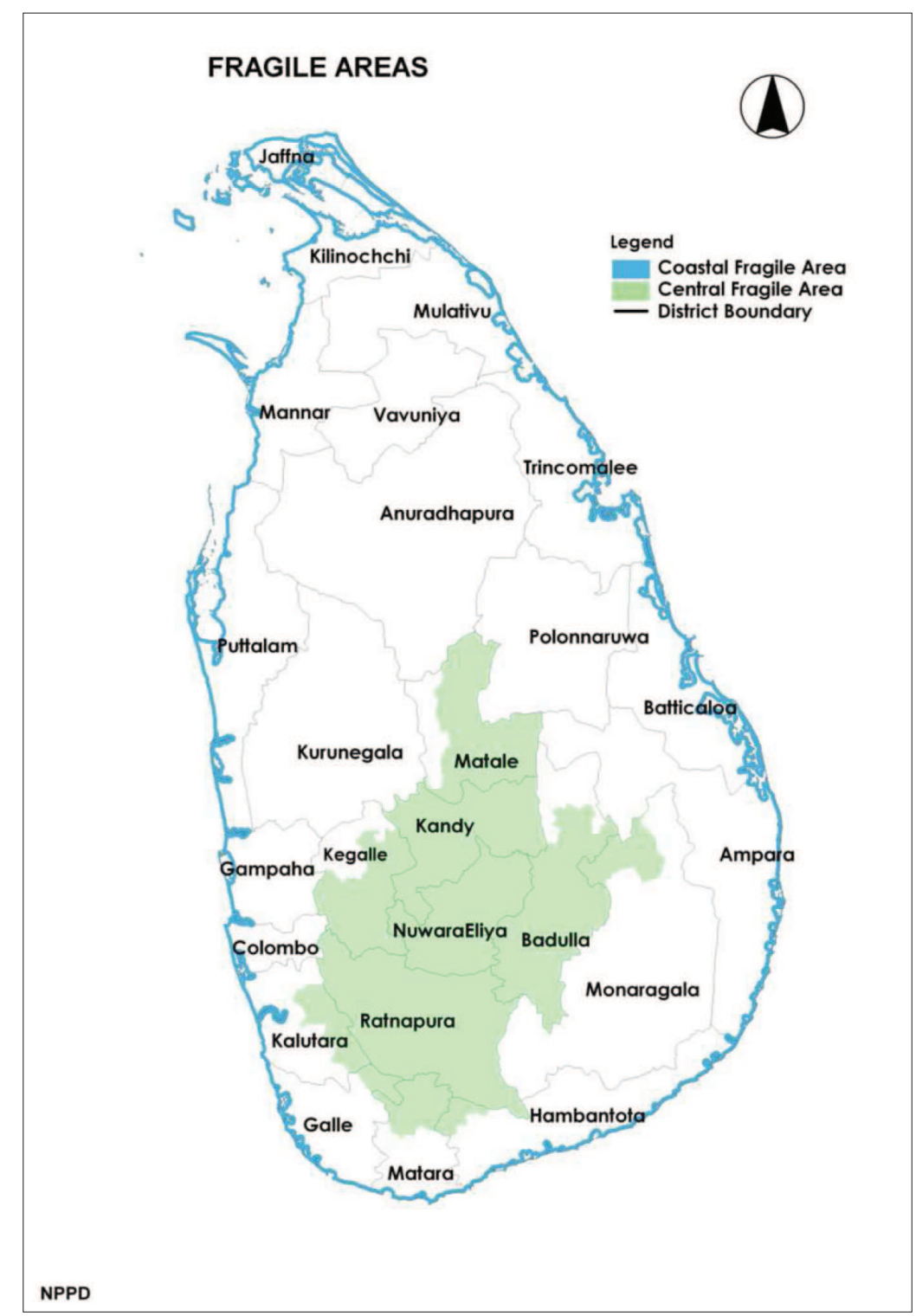

Figure 3: Fragile areas identified in the National Physical Plan for Sri Lanka (from NPPD)

spices. These small plots of land in most instances, are parts of the ridge-valley catenary landscape, so typical of Sri Lankan topography. Each village in the past had its own system of local catchments and irrigation canals to make the livelihoods of villagers sustainable. To move towards a greener economy while learning from these time-tested indigenous experiences and imaginatively incorporating them through innovative strategic planning and implementation is the need of the hour. We do have the potential and the capacity to develop appropriate models for greening the forestry as well as other related sectors in meeting our own sustainable development goals. The challenge now is to redefine the vision for forests of Sri Lanka in the light of the emerging sustainable development goals and build the necessary in-country capacity to demonstrate its benefits to policy makers in our move towards a greener economy. In recognizing this urgent need, the Sri Lankan Government has established a National Council for Sustainable Development under the leadership of H.E. the President to ensure integration of environmental concerns into the economic and social development processes in the country. The recent initiatives such as Haritha Lanka, Divi Neguma and the concept of 'one forest for one village (and one reservoir/ wetland)' are some promising national endeavours, which if properly implemented could make Sri Lanka's green growth a reality. 


\section{REFERENCES}

1. Agrawal A., Cashore B., Hardin R., Shepherd G., Benson C. \& Miller D. (2013). Economic contributions of forests. Background paper 1. United Nations Forum on Forests $10^{\text {th }}$ Session, 08 - 19 April, Istanbul, Turkey.

2. Anonymous (2011). Gazette of the National Physical Planning Policy Plan and key projects approved by the National Physical Planning Council. NPP 2011-2030. . Gazette No: 1729/15, October 27, 2011.

3. Dye P. \& Versfeld D. (2007). Managing the hydrological impacts of South African plantation forests: an overview. Forest Ecology and Management 251: 121 - 128.

4. Echavarría M. (2002). Financing watershed conservation: the FONAG water fund in Quito, Ecuador. Selling Forest Environmental Services: Market based Mechanisms for Conservation and Development (eds. S. Pagiola, J. Bishop \& N. Landell-Mills), pp. 91 - 102. Earthscan, London, UK.

5. Food and Agriculture Organization (FAO) (2008). Forests and Water. FAO Forestry Paper 154. Food and Agriculture Organization of the United Nations, Rome, Italy.

6. Gunatilleke N. (1988). Forestry master plan - a critique. Forest Conservation and Forestry Master Plan for Sri Lanka-A Review (eds. R. Fernando \& S.W.R. Samarasighe). Wildlife and Nature Protection Society of Sri Lanka, Colombo.

7. Gunatilleke I.A.U.N. \& Gunatilleke C.V.S. (1993). Forest conservation and forestry development in Sri Lanka. Conflicts and Compromise: Ecology and Landscape Management in Sri Lanka. Proceedings of the International and Interdisciplinary Symposium (eds. W. Erdelen, C. Preu, N. Ishwaran \& C.M. Maddma Bandara), pp. 243 - 254.

8. Millennium Ecosystem Assessment (MA) (2005). Ecosystems and Human Well Being: Synthesis. Island Press, Washington DC, USA.

9. Ministry of Land and Land Development (2010). National Physical Planning Policy and Plan (NPPD), Sri Lanka 2011 -2030, pp. 104. Land Use Policy Planning Department, Ministry of Land and Land Development, Battaramulla,

10. Pagiola S. (2008). Payments for environmental services in Costa Rica. Ecological Economics 65(4): 712 - 724.

11. Pagiola S. \& Platais G. (2007). Payments for Environmental Services: From Theory to Practice. World Bank, Washington DC, USA.

12. Perrot-Maitre D. (2006). The Vittel Payments for Ecosystem
Services: a "Perfect" PES Case? International Institute for Environment and Development (IIED), London, UK.

13. RIO + 20 (2012). The Future We Want: The outcome document of RIO +20 . Available at http://www.uncsd2012.org/content/documents/ TheFutureWeWant20June201230pm.pdf.

14. Schuyt K. \& Brander L.M. (2004). Economic Values of Global Wetlands. World Wildlife Fund (WWF) International, Gland, Switzerland.

15. System of Environmental-Economic Accounting (SEEA) (2012). System of Environmental-Economic Accounting 2012: Central Framework, pp. 295. United Nations, New York, USA. Available at http://unstats.un.org/unsd/ envaccounting/White_cover.pdf.

16. ten Brink P., Mazza L., Badura T., Kettunen M. \& Withana S. (2012). Nature and its Role in the Transition to a Green Economy. The Economics of Ecosystems and Biodiversity (TEEB) Final Report. Institute for European Environmental Policy, London, UK.

17. The Economics of Ecosystems and Biodiversity (TEEB) (2010). The Economics of Ecosystems and Biodiversity Report for Business - Executive Summary 2010. Available at http://www.unepfi.org/fileadmin/biodiversity/ TEEBforBusiness_summary.pdf.

18. The World Bank (2012). Inclusive Green Growth: The Pathway to Sustainable Development. The World Bank, Washington DC, USA.

19. Trucost PLC (2013). Natural Capital at Risk: The Top 100 Externalities of Business. Available at http://www. naturalcapitalcoalition.org/about/how/natural-capitalrisk.html

20. United Nations Environment Programme (UNEP) (2011). Towards A Green Economy: Pathways to Sustainable Development and Poverty Eradication - A Synthesis for Policy Makers, pp. 45. United Nations Environment Programme, Nairobi, Kenya. Available at www.unep.org/ greeneconomy.

21. United Nations Statistics Division. Handbook of National Accounting: Integrated Environmental and Economic Accounting - An Operational Manual. Statistics Division, United Nations, New York, USA. Available at http:// unstats.un.org/unsd/pubs/gesgrid.asp?id $=235$

22. van Wilgen B.W. \& Richardson D.M. (2012). Three centuries of managing introduced conifers in South Africa: benefits, impacts, changing perceptions and conflict resolution. Journal of Environmental Management 106: $56-68$. 